\title{
PENGARUH TEMPERATUR TUANG DENGAN JENIS MATERIAL AI PADUAN (RONGSOK WAJAN) TERHADAP KEKERASAN HASIL PENGECORAN EVAPORATIVE
}

\author{
Taufiq Hidayat $^{1)}$, Mastiadi Tamjidillah ${ }^{2)}$ \\ ${ }^{1,2}$ Program Studi Teknik Mesin \\ Fakultas Teknik Universitas Lambung Mangkurat \\ Jl. Akhmad Yani Km. 36 Banjarbaru, Kalimantan selatan, 70714 \\ Telp. 0511-4772646, Fax 0511-4772646 \\ E-mail: Upicktmo2@gmail.com
}

\begin{abstract}
The objective of this research is to know the effect of casting temperature with the kind of guide material Al alloy junk from pan on hardness (the evaporative foundry result). The recycling of used aluminum is an alternative to reduce the waste material from aluminum. Recycling is a way of processing used materials that is started with selection, collection, then the process of foundry to create a new product that is more valuable economical. Casting temperature is an variable that can effect the result of foundry where if the casting temperature is low, then there will be a quick freeze before the mold is completely filled. And if the casting temperature is too high, then shrinkage can occur and the porosity value may increase. This research used four casting temperature variations, namely: $650^{\circ} \mathrm{C}, 700^{\circ} \mathrm{C}, 750^{\circ} \mathrm{C}$, and $800^{\circ} \mathrm{C}$. The evaporative foundry method uses styrofoam pattern that is piled up into sand mold. The metal that is casted will form like styrofoam pattern. The result of casting temperature testing can effect on hardness.
\end{abstract}

Keywords: Evaporative, Casting Temperature, Aluminium, Pan

\section{PENDAHULUAN}

Aluminium ialah unsur kimia, lambang Aluminium ialah $A l$, dan nomor atomnya 13. Aluminium adalah logam yang paling berlimpah. Aluminium bukan merupakan jenis logam berat, namun merupakan elemen yang berjumlah sekitar $8 \%$ dari permukaan bumi dan paling berlimpah ketiga. Aluminium konduktor listrik yang baik. Ringan dan kuat. Merupakan konduktor yang baik juga untuk panas. Dapat ditempa menjadi lembaran, ditarik menjadi kawat dan diektrusi menjadi batangan dengan bermacam-macam penampang dan juga tahan korosi. Aluminium digunakan dalam banyak hal, salah satunya digunakan dalam kabel bertegangan tinggi. Juga secara luas digunakan dalam bingkai jendela dan badan pesawat terbang, ditemukan dirumah sebagai panci,botol minuman ringan, tutup botol susu dsb, dan komponen-komponen otomotif anatara lain velg, tabung sok, sepatu kampas rem, blok mesin dsb.

Salah satu keuntungan aluminium adalah,dapat di daur ulang yaitu di cor kembali menjadi produk. Mendaur ulang aluminium hanya mengkonsumsi energi sebesar $5 \%$ dari yang digunakan dalam memproduksi aluminium dari bahan tambang. Di Eropa, terutama di negara Skandinavia, 95\% aluminium yang beredar merupakan bahan hasil daur ulang. Proses awal daur aluminium berawal dari kegiatan meleburkan sampah aluminium. hal ini akan menghasilkan endapan. Endapan ini dapat diekstraksi ulang untuk mendapatkan aluminium, dan limbah yang dihasilkan dapat digunakan sebagai bahan campuran aspal dan beton karena merupakan limbah yang berbahaya bagi alam (Hafizh dkk, 2009). 
Salah satu kegiatan daur ulang yang dapat dilakukan pada aluminium adalah melalui proses peleburan. Peleburan logam adalah proses mencairkan logam pada temperature tertentu dengan menggunakan energi panas yang dihasilkan oleh tungku. Tungku adalah sebuah peralatan yang digunakan untuk melelehkan logam. Namun industri pengecoran biasanya tidak menentukan suhu lebur yang sesuai sehingga hasil coran tidak kuat.

Dari permasalahan diatas penulis ingin meneliti pengaruh temperatur tuang terhadap uji kekerasan dan porositas dan memanfaatkan limbah dari aluminium menjadi suatu produk yang bernilai ekonomis dan bisa digunakan kembali dalam bentuk dan fungsi yang berbeda.

Tujuan penelitian ini adalah untuk mengetahui pengaruh temperatur tuang material Al (scrap) wajan terhadap uji kekerasan hasil pengecoran evaporative.

\section{Pengecoran Logam}

Pengecoran (casting) adalah suatu proses penuangan material cair seperti logam atau plastik yang dimasukkan ke dalam cetakan, kemudian dibiarkan membeku di dalam cetakan tersebut, dan kemudian dikeluarkan atau di pecahpecah untuk dijadikan komponen mesin. Pengecoran digunakan untuk membuat bagian mesin dengan bentuk yang kompleks (Surdia, 2000).

Pengecoran merupakan suatu proses manufaktur yang menggunakan logam cair dan cetakan untuk menghasilkan parts dengan bentuk yang mendekati bentuk geometri produk jadi. Karena keunggulannya yang dapat menghasilkan produk dengan bentuk yang sederhana sampai yang rumit dengan berat bervariasi, mulai dari satuan gram hingga mencapai ton serta proses finishing-nya yang minimum sehingga dapat mengurangi biaya dan waktu proses, proses ini banyak digunakan di dunia industri terutama industri otomotif.

\section{Pengecoran Evaporative}

Pengecoran evaporative (evaporative casting) adalah salah satu metode pengecoran logam, dimana pola (pattern) dan sistem saluran (gatting system) menjadi satu kesatuan yang dibuat dari bahan styro foam. Proses pengecon ini dilakukan dengan cara pola dan sistem saluran dari styrofoam di tanam dalam pasir cetak. Cawan tuang (pouring basin) dengan posisi muncul di permukaan pasir cetak, sebagai saluran masuk logam cair. Proses penuangan dilakukan dengan cara, logam cair dituang pada cawan tuang, sehingga bersamaan dengan logam cair masuk mengisi posisi sistem saluran dan pola yang terbakar (mencair/menguap). Pola polystyrene foam yang dituang cairan logam dapat membentuk gas (adanya ruang pemisah) antara logam cair dan pola yang belum terkena cairan.

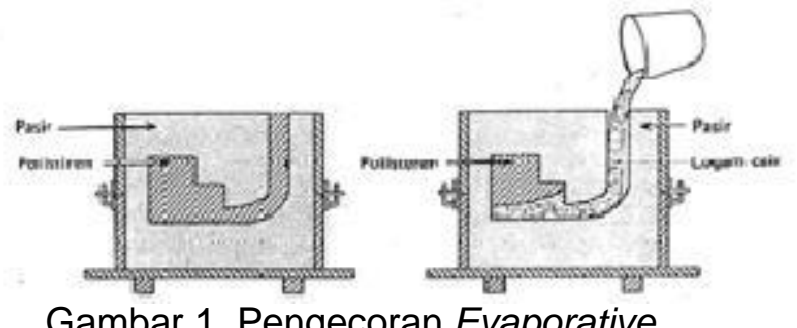

Gambar 1. Pengecoran Evaporative

\section{Aluminium}

Aluminium (Al) merupakan logam ringan yang mempunyai sifat tahan terhadap korosi dan hantaran listrik yang baik. Aluminium biasa dipergunakan untuk peralatan rumah tangga, material pesawat terbang, otomotif, kapal laut, konstruksi dan lain-lain. Untuk mendapatkan peningkatan kekuatan mekanik, biasanya logam aluminium dipadukan dengan unsur $\mathrm{Cu}, \mathrm{Si}, \mathrm{Mg}, \mathrm{Zn}, \mathrm{Mn}, \mathrm{Ni}$, dan 
unsur lain (Surdia, 1991). Aluminium merupakan logam yang banyak digunakan dalam berbagai aplikasi. Produk-produk aluminium sering dihasilkan melalui proses pengecoran (casting) dan pembentukan (forming). Aluminum hasil pengecoran banyak dijumpai pada peralatan rumah tangga dan komponen otomotif misalnya velg, piston, sepatu kampas rem, blok mesin, puli dan lain sebagainya.

\section{Paduan Aluminium}

Aluminium murni relatif lunak dan penambahan unsur paduan dapat meningkatkan sifat mekanisnya. Pengelompokan paduan Al didasarkan pada jenis unsur paduan dengan menggunakan sistem 4 digit dimana digit pertama menunjukkan kelompok aluminium, digit kedua menunjukkan modifikasi dari paduan aslinya atau Batas unsur pengotor dan 2 digit terakhir menunjukkan kemurnian aluminium. Paduan aluminium dapat dikelompokkan menjadi paduan yang tidak bisa diberi perlakuan panas (non heat treatable alloy) dan paduan yang dapat diberi perlakuan panas (heat treatable alloy).

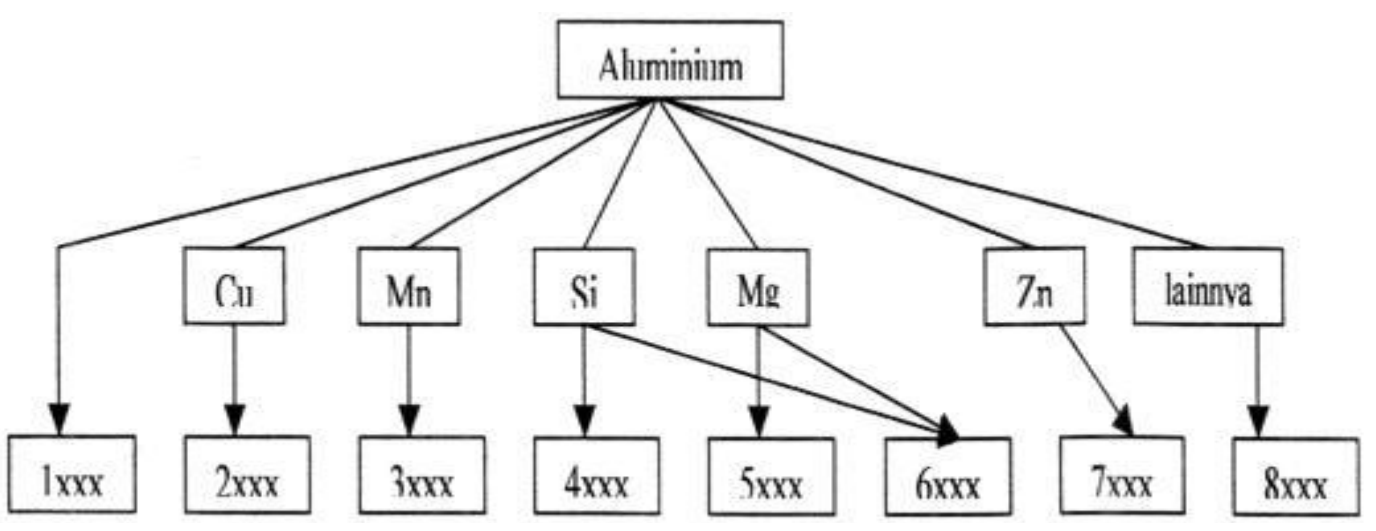

Gambar 2. Klasifikasi Aluminium dan Paduannya

\section{Cetakan}

Adapun bagian - bagian dalam cetakan yang perlu disiapkan sebelum penuangan cairan logam (coran), yaitu sebagai berikut :

1. Pola

Pada pengecoran evaporative dengan pola Styrofoam, saluran turun dan bagian dari sistem saluran masuk merupakan bagian dari pola. Pola, saluran turun dan saluran tuangnya ditinggalkan dalam cetakan. Pada saat proses pencetakan, pola yang umumnya terbuat dari polistiren akan menguap dan logam cair akan mengisi rongga cetakan (Surdia dan Chijiiwa,1975).

\section{Pasir cetak}

Pasir cetak yang digunakan pada pengecoran evaporative bisa dari pasir silika, pasir zirkon, pasir olivine dan kromate (pasir gunung, pantai, sungai). Pasir cetak bias digunakan berulang dan dalam jangka yang lama. Pasir cetak dapat digunakan secara terus menerus selama masih mampu menahan temperatur cairan ketika dituangkan (Lal,1981).

\section{Rangka cetak}

Rangka cetak merupakan alat atau rangka yang terbuat dari kayu maupun logam yang berbentuk segi empat atau bulat yang digunakan untuk membuat cetakan. Cetakan sendiri merupakan alat yang berisi pasir cetak yang sudah diisi untuk melakukan proses pengecoran. 


\section{Temperatur Tuang}

Temperatur tuang adalah salah satu unsur penting yang harus diperhatikan dalam memproduksi produk pengecoran yang berkualitas tinggi, karena faktor ini sangat berpengaruh terhadap kualitas coran yang meliputi mikro struktur dan sifat mekanis sehingga didapatkan hasil coran yang mempunyai sifat fisik yang baik. Temperatur tuang merupakan salah satu variabel dari sekian banyak variabel yang terdapat pada proses pengecoran. Variabel ini penting karena jika temperatur tuang terlalu rendah maka rongga cetakan tidak akan terisi penuh dimana logam cair akan membeku terlebih dahulu pada saluran masuk, dan jika temperatur tuang terlalu tinggi maka hal ini akan mengakibatkan penyusutan dan kehilangan akan keakuratan dimensi coran. Bentuk dari diagram fasa dari paduan Al ditunjukkan sebagaimana Gambar 3.

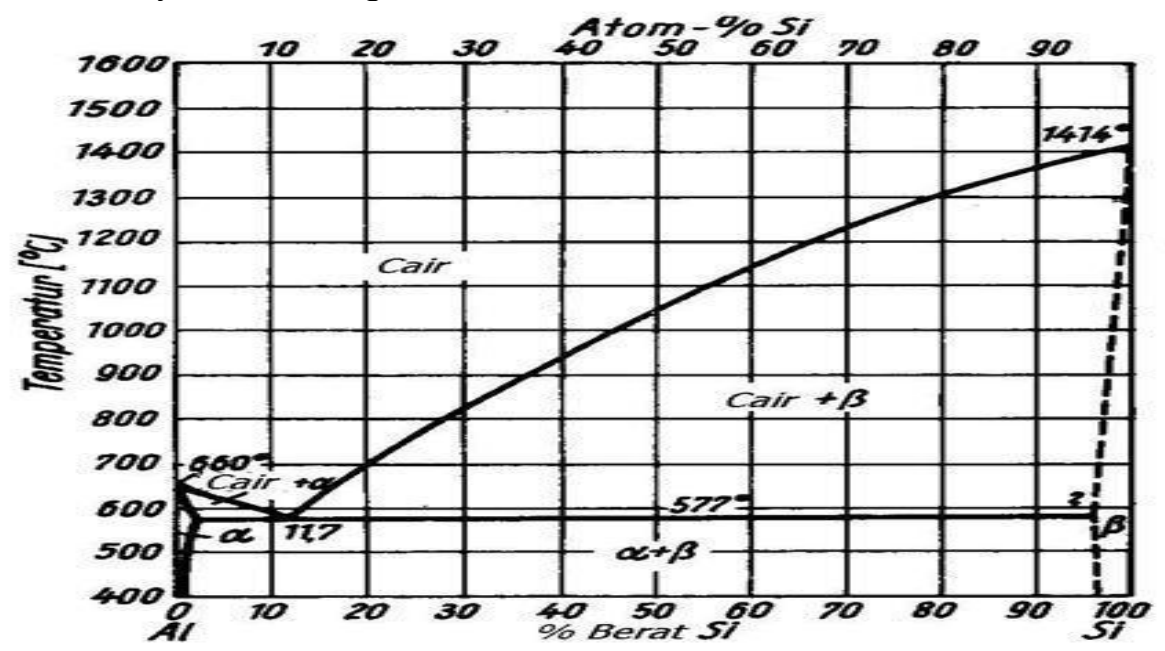

Gambar 3 Diagram Fasa Al-Si berikut:

Kandungan silika pada diagram fasa Al-Si ini terdiri dari 3 macam sebagai

1. Hipoeutectic yaitu apabila terdapat kandungan silika kurang dari $11,7 \%$ dimana struktur akhir yang terbentuk pada fasa ini adalah struktur ferrite kaya aluminium, dengan struktur eutetik sebagai tambahan.

2. Eutectik yaitu apabila kandungan silika yang terkandung didalam sekitar $11,7 \%$ sampai $12,6 \%$ pada komposisi ini Al-Si dapat membeku secara langsung dari fasa cair kepadat.

3. Hypereutectic yaitu apabila komposisi silika diatas $12,6 \%$ sehingga kaya akan silika dengan fasa eutektik sebagai fasa tambahan. Keberadaan Kristal silika primer pada daerah ini mengakibatkan karakteristik sebagai berikut:

a. Ketahanan aus paduan meningkat.

b. Ekspansi termal rendah.

c. Memiliki ketahan retak panas yang baik.

\section{Pengujian}

1. Kekerasan vicker

Pengujian kekerasan Vickers menggunakan mata penumbuk piramida intan yang berbentuk bujur sangkar. Angka kekerasan piramida intan (DPH) atau angka kekerasan Vickers (VHN atau Hv), didefinisikan sebagai beban dibagi luas permukaan lekukan. Luas ini dihitung dari pengukuran mikroskopik panjang diagonal jejak. VHN dapat ditentukan dengan persamaan berikut :

$\mathrm{VHN}=1,8544 . \mathrm{P} / \mathrm{d}^{2}$ 
Keterangan:

$\mathrm{P}=$ beban yang bekerja pada penetrator intan $(\mathrm{kg})$

$\mathrm{d}=$ panjang diagonal rata-rata bekas penekan $(\mathrm{mm})$

Pada hasil pengujian, lekukan yang benar yang dibuat oleh penumbuk piramida intan harus berbentuk bujur sangkar. Waktu yang diperlukan untuk penekanan 5 detik, dengan beban $1-100 \mathrm{~kg}$.

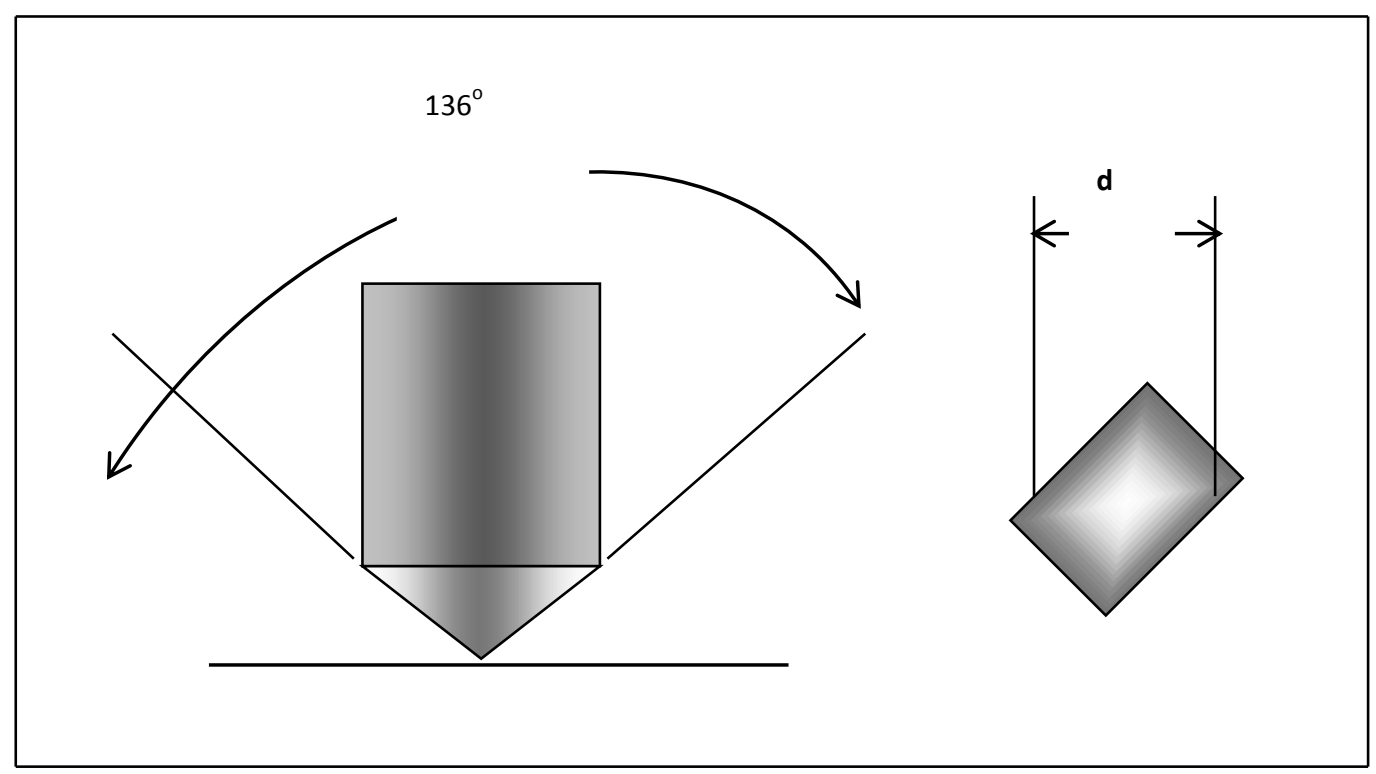

Gambar 4. Indentor Vickers

\section{Porositas}

Porositas adalah suatu cacat (void) pada produk cor yang dapat menurunkan kualitas benda tuang. Salah satu penyebab terjadinya porositas pada penuangan paduan aluminium adalah gas hidrogen. Porositas oleh gas hidrogen dalam benda cetak paduan aluminium-silika akan memberikan pengaruh yang buruk pada kekuatan, serta kesempurnaan dari benda tuang tersebut. Penyebabnya antara lain kontrol yang kurang sempurna terhadap absorbsi gas oleh paduan, pegeluaran gas dari dalam logam karena interaksi antara gas dengan logam selama peleburan dan penuangan (Firdaus, 2002).

Menurut sudarsono (2008) dan amir (2008) porositas dihitung melalui pengukuran massa jenis, melalui pengukuran berat spesimen diudara dan di dalam air murni. Massa jenis aktual spesimen ditentukan dengan menggunakan rumus Archimedes berdasarkan standar ASTM D3800 :

$D a=\frac{W a \cdot D w}{W a-W w}$

Keterangan:

$D_{a}=$ massa jenis actual

$D_{\mathrm{w}}=$ massa jenis air

$\mathrm{W}_{\mathrm{a}}=$ berat spesimen dalam udara

$\mathrm{W}_{\mathrm{w}}=$ berat spesimen dalam air

Untuk mencari persentase dari tingkat porositas dapat dicari menggunakan rumus standar ASTM C948:

$P \%=\left(\frac{D t-D a}{D t}\right) \times 100 \%$ 
Keterangan:

$\mathrm{P} \%=$ porositas

$D t \quad=$ massa jenis teoritis aluminium paduan $\left(2,74 \mathrm{gr} / \mathrm{cm}^{3}\right)$

$\mathrm{Da} \quad=$ massa jenis aktual aluminium paduan $\left(\mathrm{gr} / \mathrm{cm}^{3}\right)$

\section{METODE PENELITIAN}

Metode yang digunakan dalam penelitian ini adalah metode eksperimen. Material rongsok wajan dilebur dalam tungku krusibel kemudian dituang dengan temperatur $(650,700,750 \text {, dan } 800)^{\circ} \mathrm{C}$ dalam cetakan selanjutnya ditunggu dalam pasir cetak dengan waktu tunggu 20 menit. Hasil pengecoran dibuat spesimen dan diuji dilaboratorium untuk mengetahui porositas dan kekerasan.

\section{Variabel Penelitian}

Pengecoran dilakukan menggunakan metode pengecoran tuang (tanpa tekanan) dengan variasi temperatur tuang $\left(650^{\circ} \mathrm{C} 700^{\circ} \mathrm{C}, 750{ }^{\circ} \mathrm{C}\right.$, dan $\left.800^{\circ} \mathrm{C}\right)$. dan jenis material daur ulang (scrap wajan).

\section{Variabel Bebas}

1. Jenis material (scrap wajan).

2. Temperatur tuang $\left(650^{\circ} \mathrm{C} 700^{\circ} \mathrm{C}, 750^{\circ} \mathrm{C}\right.$, dan $\left.800^{\circ} \mathrm{C}\right)$.

\section{Variabel Terikat}

1. Porositas.

2. Kekerasan.

\section{Variabel Kontrol}

1. Pendinginan temperatur tuang.

2. Ukuran pasir dan volume pasir dalam cetakan.

3. Waktu tunggu dalam cetakan 20 menit.

4. Rangka cetak.

5. Pola styrofoam.

\section{Persiapan}

Jalannya penelitian dilakukan melaui beberapa tahap termasuk persiapan. Persiapan yang dilakukan sebagaimana yang telah dijelaskan sebelumya antara lain :

1. Peralatan

Peralatan yang harus disiapkan dalam penelitian ini adalah peralatan pengecoran, peralatan ukur suhu dan waktu, peralatan uji dan peralatan preparasi.

2. Bahan

Bahan yang harus dipersiapkan adalah bahan baku coran yaitu $\mathrm{Al}$ rongsokan (scrap) wajan rumah tangga.

\section{Peleburan dan Penuangan}

Panaskan terlebih dulu tungku krusibel dengan bahan bakar arang kayu yang sebelumnya sudah dinyalakan sampai temperatur tungku merata. Dimana konsumsi udaranya bisa diatur melalui jendela udara. Ketika warna cawan peleburan (kowi) sudah berwarna merah membara dan panas tungku sudah tercapai, masukkan bahan baku coran yaitu coran rongsokan (scrap) wajan yang sebelumnya sudah dibersihkan dan dipotong menjadi beberapa bagian.

Setelah aluminium mencair, tuangkan aluminium cair kedalam cetakan pasir dengan variasi temperatur tuang $\left(650^{\circ} \mathrm{C}, 700^{\circ} \mathrm{C}, 750^{\circ} \mathrm{C}\right.$ dan $\left.800^{\circ} \mathrm{C}\right)$. 
Dimana setelah penuangan selesai coran didiamkan didalam cetakan dengan waktu pendinginan dalam cetakan 20 menit.

\section{HASIL DAN PEMBAHASAN}

Pengujian Kekerasan

Tabel 1.

Adapun data hasil pengujian kekerasan ditunjukan dalam

\begin{tabular}{|l|c|c|c|c|c|}
\hline \multicolumn{1}{|c|}{ Tabel 1. Hasil uji kekerasan } \\
\hline \multirow{2}{*}{ No } & $\begin{array}{c}\text { Material Al } \\
\text { Rongsok (wajan) }\end{array}$ & \multicolumn{5}{|c|}{ Temperatur tuang ${ }^{\circ} \mathbf{C}$} \\
\cline { 5 - 7 } & $\mathbf{6 5 0}$ & 700 & 750 & 800 \\
\hline 2 & Replikasi 1 & 85 & 92 & 95 & 93 \\
\hline 3 & Replikasi 2 & 80 & 89 & 93 & 91 \\
\hline 4 & Replikasi 3 & 85 & 90 & 94 & 92 \\
\hline
\end{tabular}

Hasil dari pengujian kekerasan pada material rongsok rumah tangga (wajan), kekerasan tertinggi ditunjukan pada temperatur $750^{\circ} \mathrm{C}$ yaitu $94 \mathrm{~kg} / \mathrm{mm}^{2}$, dan kekerasan terendah ditunjukan pada temperatur $650^{\circ} \mathrm{C}$ yaitu $83 \mathrm{~kg} / \mathrm{mm}^{2}$.

\section{Pengujian Porositas Material Wajan}

Pengujian porositas dilakukan untuk mengetahui tingkat porositas pada setiap temperatur suhu tuang proses pengecoran seperti ditunjukan dalam Tabel 2.

Tabel 2 Hasil uji porositas

\begin{tabular}{|c|c|c|c|}
\hline $\begin{array}{c}\text { Kode } \\
\text { sepesimen }\end{array}$ & Udara (gram) & Air (gram) & Porositas (\%) \\
\hline A & 6,933 & 4,368 & 1,649 \\
\hline B & 6,645 & 4,197 & 1,229 \\
\hline C & 6,663 & 4,221 & 0,718 \\
\hline D & 6,655 & 4,201 & 0,512 \\
\hline
\end{tabular}

Hasil dari pengujian porositas pada material rongsok rumah tangga (wajan), porositas tertinggi ditunjukan pada kode sepesimen $\mathrm{A}$ yaitu $800^{\circ} \mathrm{C}$ dengan nilai porositas $1,649 \%$ dan porositas terendah ditunjukan pada kode sepesimen $D$ yaitu $650^{\circ} \mathrm{C}$ dengan nilai porositas $0,512 \%$.

\section{Pengujian Struktur Mikro}

Pengujian struktur mikro dilakukan untuk mengetahui struktur mikro dari setiap temperatur tuang, adapun hasil pengujian seperti pada Gambar 5. 


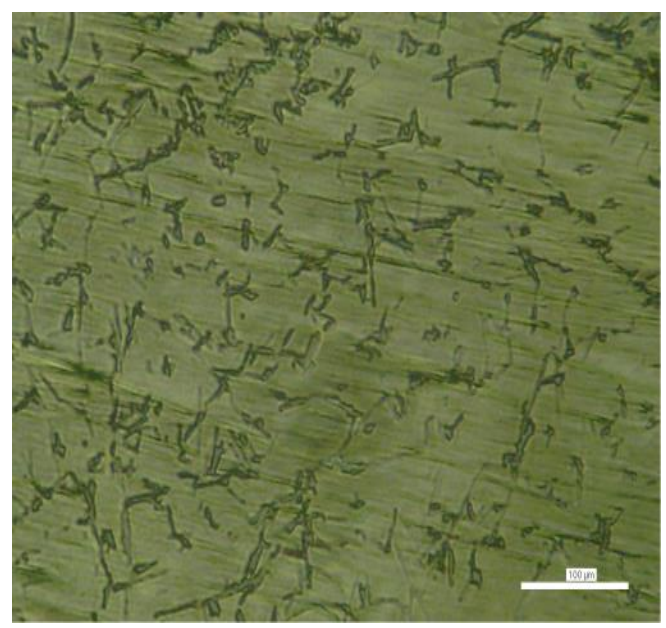

$650^{\circ} \mathrm{C}$

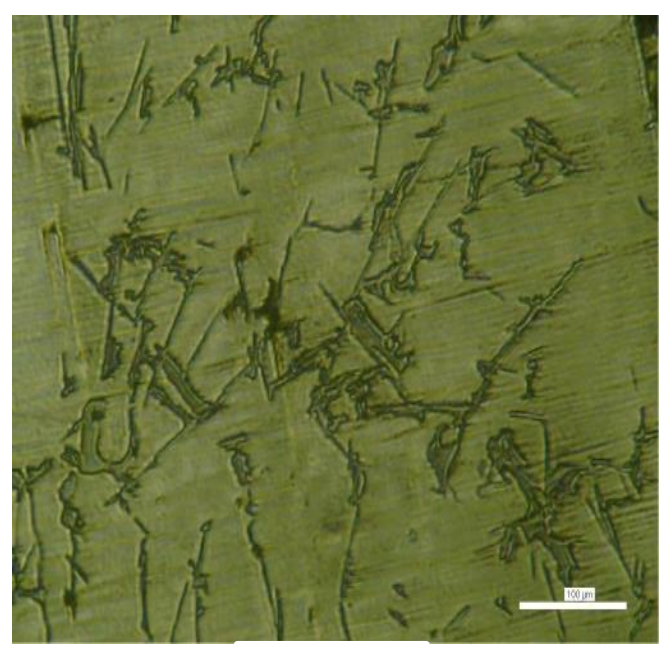

$750^{\circ} \mathrm{C}$

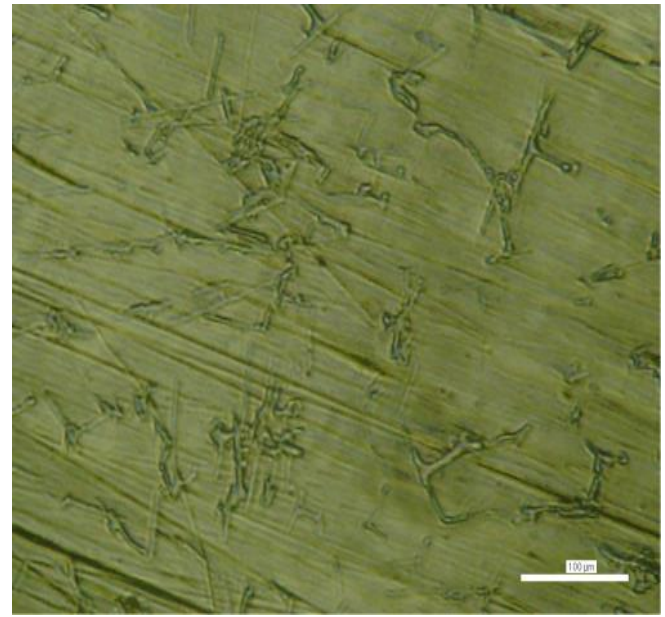

$700^{\circ} \mathrm{C}$

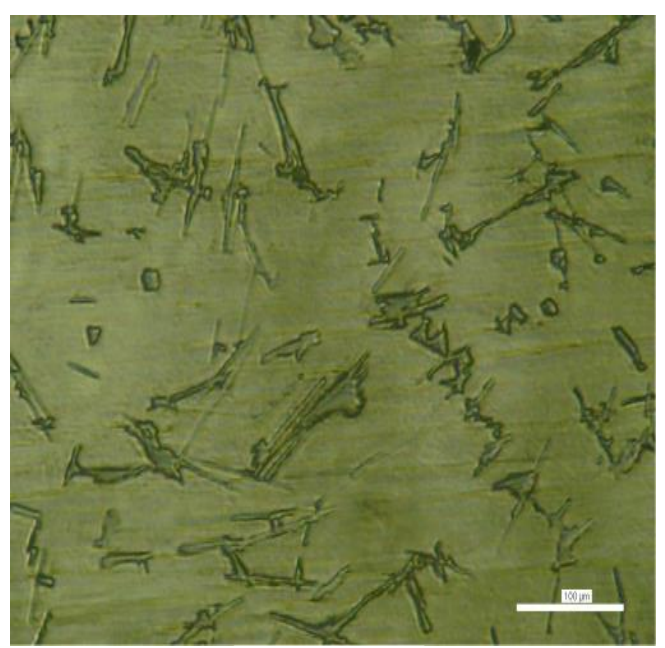

$800^{\circ} \mathrm{C}$

Gambar 5. Hasil Pengujian Struktur Mikro

\section{Kekerasan dan Porositas}

Pengujian kekerasan dilakukan untuk mengetahui tingkat kekerasan pada setiap spesimen yang diberi variasi temperatur tuang dan didapatkan data sebagai berikut:

Uji Kekerasan

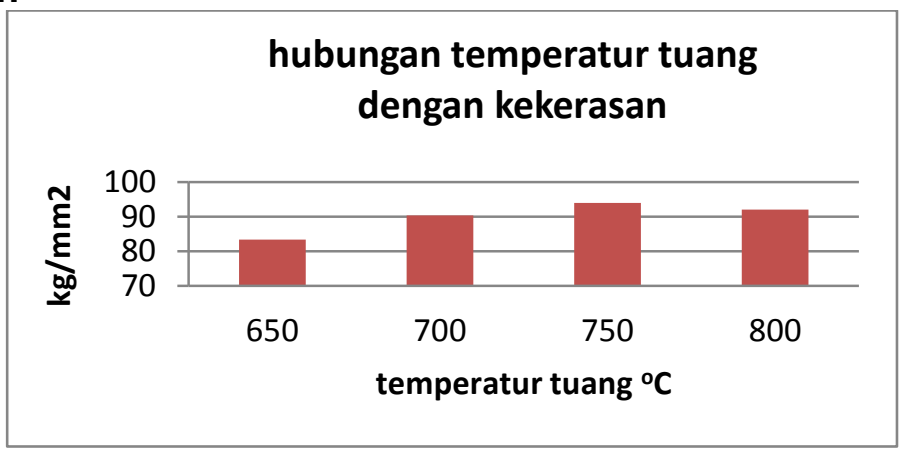

Gambar 6. Hasil Uji Kekerasan Pada Material Al Rongsok 
Dari Gambar 6 didapatkan tingkat kekerasan pada temperatur $650^{\circ} \mathrm{C}$ didapatkan nilai kekerasan $83,3 \mathrm{~kg} / \mathrm{mm}^{2}$ lalu pada temperatur $700^{\circ} \mathrm{C}$ naik mencapai $90,3 \mathrm{~kg} / \mathrm{mm}^{2}$ dan pada temperatur $750^{\circ} \mathrm{C}$ naik kembali hingga 94 $\mathrm{kg} / \mathrm{mm}^{2}$ kemudian turun lagi pada temperatur $800^{\circ} \mathrm{C}$ dengan tingkat kekerasan $92 \mathrm{~kg} / \mathrm{mm}^{2}$, dari Gambar 6 terlihat kenaikan temperatur berpengaruh terhadap kenaikan tingkat kekerasan dari $650^{\circ} \mathrm{C}-750^{\circ} \mathrm{C}$ namun turun kembali pada saat temperatur $800^{\circ} \mathrm{C}$, sehingga dapat ditarik kesimpulan yaitu semakin tinggi temperatur tuang maka semakin tinggi nilai kekerasan namun jika terlalu tinggi temperatur tuang juga akan menurunkan nilai kekerasan.

\section{Uji Porositas}

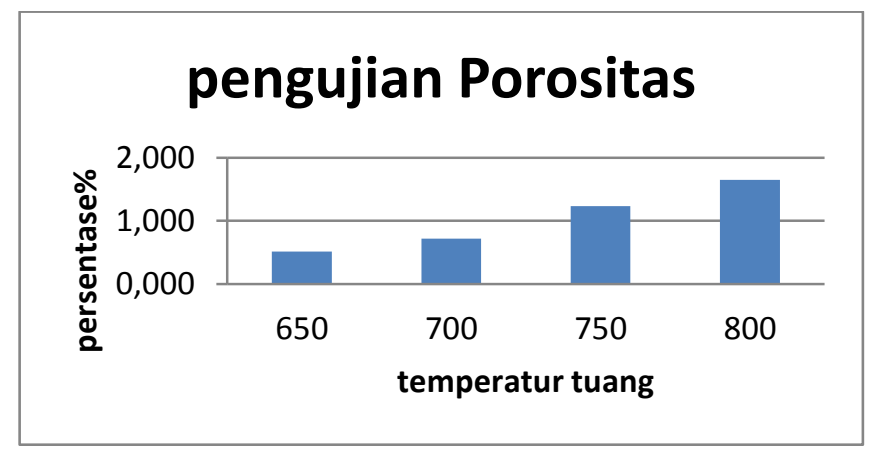

Gambar 7. Hasil Uji Porositas

Dari Gambar 7 terlihat hasil penelitian porositas rongsok wajan temperatur tuang $650^{\circ} \mathrm{C}$ hampir mendekati $0 \%$, pada temperatur $700^{\circ} \mathrm{C}$ ada peningkatan porositas yaitu $0,718 \%$, pada temperatur tuang $750^{\circ} \mathrm{C}$ porositas meningkat menjadi $1,229 \%$ kemudian pada temperature $800^{\circ} \mathrm{C}$ porositas kembali naik menjadi $1,649 \%$.

\section{Uji Analisis Varian (ANOVA)}

Hasil analisis ANOVA untuk data penelitian ini dapat di lihat dalam Tabel 3. Tabel 3. Hasil analisis ANOVA

\begin{tabular}{|l|r|r|r|r|r|}
\hline & Sum of Squares & df & Mean Square & F & Sig. \\
\hline Between Groups & 193.583 & 3 & 64.528 & 20.377 & .000 \\
Within Groups & 25.333 & 8 & 3.167 & & \\
Total & 218.917 & 11 & & & \\
\hline
\end{tabular}

Hasil dari pengujian Anova menggunakan aplikasi Statistical Product and Service Solutions (SPSS), pada kolom signifikan menunjukan hasil 0,000 yang lebih kecil dari 0,05 maka dapat disimpulkan bahwa menerima $\mathrm{H}_{1}$ dan menolak $\mathrm{H}_{0}$ yang berarti ada perbedaan secara nyata atau signifikan hasil uji kekerasan antar perbedaan suhu tuang.

\section{Pembahasan}

Berdasarkan hasil pengamatan pada foto struktur mikro, pada jenis material Al rongsok (wajan) terlihat susunan struktur mikro yang didominasi oleh Al seperti terlihat pada Gambar 5 terlihat kandungan selain Al yang membentuk seperti garis-garis kecil yang tersebar merata. Kandungan ini mengindikasikan adanya kandungan Si dalam Al paduan (Hermawan, dkk, 2013).

Dari Gambar 7 dan 6 dapat dilihat material rongsok wajan ketika temperatur tuang $650^{\circ} \mathrm{C}$ mempunyai tingkat kekerasan $83,3 \mathrm{~kg} / \mathrm{mm}^{2}$ dengan porositas $0,512 \%$ karena Al belum dalam temperatur menguap lihat Gambar 5 
$650^{\circ} \mathrm{C}$ terlihat dentrite yang banyak, ketika temperatur tuang $700^{\circ} \mathrm{C}$ tingkat kekerasan naik menjadi $90,3 \mathrm{~kg} / \mathrm{mm}^{2}$ dengan porositas $0,718 \%$ terlihat dari Gambar $5700^{\circ} \mathrm{C}$ dentrite mulai berkurang dan struktur mulai merata. pada temperatur tuang $750^{\circ} \mathrm{C}$ nilai kekerasan meningkat sampai $94 \mathrm{~kg} / \mathrm{mm}^{2}$ dengan nilai porositas $1,229 \%$ dan kemudian pada temperatur tuang $800^{\circ} \mathrm{C}$ kekerasan kembali menurun menjadi $92 \mathrm{~kg} / \mathrm{mm}^{2}$ dan nilai porositasnya meningkat sampai $1,649 \%$. Dapat dilihat pada pengecoran ulang Al rongsok kekerasan tertinggi ditunjukan pada temperatur tuang $750^{\circ} \mathrm{C}$ yaitu $94 \mathrm{~kg} / \mathrm{mm}^{2}$ dengan nilai porositas $1,229 \%$.

Salah satu penyebab terjadinya porositas adalah adanya gas hydrogen dan proses pembekuan, dimulai dari bagian logam yang bersentuhan dengan cetakan dimana inti kristas mulai tumbuh dan built butir itu memanjang, itu artinya semakin lama logam mengalami pembekuan dalam cetakan maka porositas semakin tinggi (Raharjo dkk 2011). Hasil terbaik pada $750^{\circ} \mathrm{C}$ dengan tingkat kekerasan $94 \mathrm{~kg} / \mathrm{mm}^{2}$ dan nilai porositas hanya $1,229 \%$ pada jenis material ini cenderung getas karena material Al paduan mengandung Si, yang menyebabkan sifat material menjadi keras. Dalam penelitian ini terlihat semakin tinggi temperatur tuang tingkat kekerasan juga naik, diikuti juga dengan kenaikan porositas, tingkat kekerasan yang meningkat ini disebabkan paduan Si yang semakin tinggi temperatur tuang maka kekuatan mengikatnya juga semakin mengikat.

Berdasarkan analisis ANOVA dengan uji lanjut LSD dan Duncan didapatkan hasil perbedaan temperatur tuang dari ketiga pengulangan yaitu $650^{\circ} \mathrm{C}, 700^{\circ} \mathrm{C}, 750^{\circ} \mathrm{C}$, dan $800^{\circ} \mathrm{C}$ memiliki pengaruh secara nyata terhadap uji kekerasan. Hal tersebut seperti terlihat pada lampiran 1 terlihat dari Tabel LSD pada kolom signifikan antara perlakuan $1\left(800^{\circ} \mathrm{C}\right)$ dengan yang lainnya ada kesamaan antar 1-2 dan 1-3 karena nilai signifikannya lebih besar dari 0,05 namun berbeda pada perlakuan 1 dengan perlakuan 4 kerena nilai signifikannya lebih kecil dari 0,05 yaitu 0,000 . Pada perlakuan $2\left(750^{\circ} \mathrm{C}\right)$ dengan yang lainnya ada perbedaan antara 2-3 dan 2-4 karena nilai signifikannya lebih kecil dari 0,05 namun ada kesamaan perlakuan 2 dengan perlakuan 1 karena nilai signifikannya lebih besar dari 0,05 yaitu 0,206 bisa dibuktikan pada baris pertama yaitu perlakuan 1-2 adalah sama. Lalu pada perlakuan $3\left(700^{\circ} \mathrm{C}\right)$ dengan yang lainnya ada perbedaan antara 3-2 dan 3-4 karena nilai signifikannya kurang dari 0,05 dan ada kesamaan pada perlakuan 3 dan perlakuan 1 karena nilai signifikannya lebih besar dari 0,05 yaitu 0,284 . Kemudian pada perlakuan $4\left(650^{\circ} \mathrm{C}\right)$ dengan yang lainnya berbeda secara nyata terhadap uji kekerasan karena nilai signifikannya lebih kecil dari 0,05. Uji lanjutan Duncan sebagai perbandingan juga menunjukan ada kesamaan antara perlakuan 3 dan perlakuan 1 yang terletak pada subset 2 dengan nilai signifikan 0,284 dan ada kesamaan pada perlakuan 1 dengan perlakuan 2 yang terletak pada subset 3 dengan nilai signifikan 0,206 , lalu ada perbedaan yang nyata pada perlakuan 4 terhadap uji kekerasan yang ditunjukan pada subset 1 dengan nilai signifikan 0,00. Dari hasil uji Anova ini kita bisa mengambil kesimpulan bahwa pada perlakuan 4 atau temperatur tuang $650^{\circ} \mathrm{C}$ tidak berpengaruh terhadapap uji kekerasan, jadi untuk pengecoran Al paduan tidak diperlukan lagi temperatur tuang $650^{\circ} \mathrm{C}$.

\section{KESIMPULAN}

Dari hasil penelitian pengaruh temperatur tuang terhadap uji kekerasan dapat disimpulkan bahwa variasi temperatur tuang berpengaruh terhadap kekerasan dapat dilihat dari hasil penelitian pada material rongsok wajan semakin tinggi temperatur tuang maka tingkat kekerasan juga semakin tinggi, namun setelah temperatur optimum tercapai kekerasan menurun bisa dilihat dari 
hasil pengujian yaitu: temperatur $650^{\circ} \mathrm{C}=83,3 \mathrm{~kg} / \mathrm{mm}^{2}$, temperatur $700^{\circ} \mathrm{C}=$ $90,3 \mathrm{~kg} / \mathrm{mm}^{2}$, temperatur $750^{\circ} \mathrm{C}=94 \mathrm{~kg} / \mathrm{mm}^{2}$, dan temperatur $800^{\circ} \mathrm{C}=92$ $\mathrm{kg} / \mathrm{mm}^{2}$.

\section{DAFTAR PUSTAKA}

Ashar dkk, 2012."Analisis Pengaruh Model Sistem Saluran Dengan Pola Styrofoam Terhadap Sifat Fisis Kekerasan Produk Puli Pada Proses Pengecoran Aluminium Daur Ulang". momentum. vol 8 no.1 jurnal teknik mesin fakultas teknik universitas wahid hasyim. semarang.

Brown, J. R, 1992 The lost foam casting poroses, netallurgy Matrial". Vol 8 pp550-555.

Darsin Mahos, Sallahudin Junus, Yopi Indra Tiawan, 2010" Analisis sifat mekanik dan struktur mikro aduan Al 5083 akibat pengelasan metal Inert gas (mig) dengan variasi srehat dan post heat', jurnal, universitas Jember, Jember.

Firdaus., 2002, "Analisis Parameter Proses Pengecoran Squeeze Terhadap Cacat Porositas Produk Flens Motor Sungai", Jurnal Teknik Mesin Vol. 4, No. 1, pp. $6-12$.

Hafizh, A., Sapto, S., Yudhi, s., Aulia, R., Yuliana., Reny, I., Rhamdani, M., Ahmad, E., 2009, "Aluminium Murni dan Paduannya", Fakultas Teknologi Pertanian Institut Pertanian Bogor.

Hermawan dkk, 2013, "Analisa Pengaruh Variasi Temperatur Tuang Pada Pengecoran Squeeze Terhadap Struktur Mikro Dan Kekerasan Produk Sepatu Kampas Rem Dengan Bahan Aluminium (Al) Silikon (Si) Daur Ulang",Momentum, Vol-9 No.2, Jurnal Teknik Mesin Ft Universitas Wahid Hasyim: Semarang. ISSN 0216-7395.

Karim Ivan Junaidy Abdul, 2012, Pengaruh Temperatur Tuang serta Ukuran Ayakan Pasir terhadap Cacat Porositas dan Blowhole Coran Al-Si7 yang Dicor dengan Metode Evaporative, Proceedings Seminar Nasional Energi erbarukan \& Produksi Bersih 2012 Universitas Lampung (UNILA), Bandar Lampung, ISSN 0016087403, hal. 71-73.

Kim, K, and Lee, K 2005, effect of Process parameters on porosity in aluminium losr foam process, journal Material Scipta Technology, Vol. 21 No 5, pp. 681-685.

Kumar, S, Kumar P,Shan H.S. 2007 Effect of evaporative pattern casting process parameters on the suraface roughness of Al-7\% Si alloy castings, journal of materials processing technology, vol. 182. Pp 12-18.

Kusharjanta bambang, wahyupurworaharjo, joko santoso, 2012, "pengaruh bentuk penampang runner terhadap cacat porositas dan nilai kekerasan produk cor aluminium cetakan pasir". Mekanika, Universitas Sebelas Maret, Surakarta.

Lal, S., Khan, R. H., 1998, Current status of vacuum sealed molding process, Indian Foundry Journal, Vol. 27, pp.12-18.

Mu'afax ferdiaz dinov, budi harjanto,suharno,2013, "pengaruh media pendingin terhadap kekerasan dan struktur mirko hasil remelting Al-Si berbasis limbah piston bekas dengan perlakukan degasing", Jurnal Nosel Vol 1,No 3, UNS kampus Jl ahmad Yani 200, Surakarta.

Raharjo dkk, 2011,"Analisis Pengaruh Pengecoran Ulang Terhadap Sifat Mekanik Paduan Alumunium ADC 12', jurnal teknik mesin fakultas teknik universitas muhammadiyah semarang ISNB. 978-602-99334-0-6.

Shin S. R. Lee Z. H. 2014" Hidrogen Fas Pick Up Of Alloy Melt During Lost Foam Casting". Journal of Material science Vol 39 1536-1569.

Surdia, T. dan Chijiiwa K., 1986, Teknik Pengecoran Logam, PT. Pradnya Paramita, Jakarta. 
Surdia, T. dan Chijiwa K., 1991, Teknik Pengecoran Logam, PT Pradnya Paramita, Jakarta.

Surdia, T. dan Chijiwa, K., 1996, “Teknik Pengecoran Logam”, Cetakan Ketujuh, Pradnya Paramita, Jakarta.

Surdia,T. dan Chijiwa, K..2000. Teknik Pengecoran Logam, Cetakan Ke-8, PT. Pradnya Paramita, Jakarta.

Siswanto, Rudi. 2015." Analisis Struktur Mikro Paduan Al-19,6 Si-2,5cu 3,2zn (Scrap) Hasil Pengecoran Evaporative". Proseding Sminar Nasional Tahunan Teknik Mesin XIV, Teknik Mesin Akademi Teknik Pembangunan Nasional. Banjarbaru.

Sutiyoki. "Metode Pengecoran Lost Foam Menjawab Tantangan Dunia Industri Pengecoran Logam". Jurnal Teknik Pengecoran Logam Politeknik Manufaktur Ceper Klaten.

Venkataramani, R, Simson R and Ravinrral, C, 1995 effect of melt superheat on maximum nuclei densityin A356 alloy.Elservier Science. Material Characterization vol 38 pp 81-92 www.lostfoam.com, 5/7/2011.

Wijoyo, Achmad Nurhidayat, Osep Teja Sulammunajat, 2012, "Kajian Komprehensif Struktur Mikro Dan Kekerasan Terhadap Paduan Al-7,1si1,5cu Hasil Pengecoran Denganmetode Evaporative", Prosiding SNST ke3 Tahun 2012 Fakultas Teknik Universitas Wahid Hasyim Semarang, ISBN 978-602-99334-1-3,hal. C.40-C.45'. 